OPEN ACCESS

Edited by:

Yongjun Wei,

Zhengzhou University, China

Reviewed by:

Yan Xia,

Nanjing Agricultural University, China Zhubing $\mathrm{Hu}$,

Henan University, China

${ }^{*}$ Correspondence:

Wenling Yang

yangwenling2016@163.com

Specialty section:

This article was submitted to Water and Wastewater Management,

a section of the journal

Frontiers in Environmental Science

Received: 10 June 2021

Accepted: 16 August 2021

Published: 27 August 2021

Citation:

Jing $Y, L i Z, L i Y$, Lei G, Li L, Yang $X$, Zhang $Z$ and Yang $W$ (2021) The Ability of Edible Fungi Residue to Remove

Lead in Wastewater.

Front. Environ. Sci. 9:723087.

doi: $10.3389 /$ fenvs.2021.723087

\section{The Ability of Edible Fungi Residue to Remove Lead in Wastewater}

\author{
Yanyan Jing ${ }^{1}$, Zongyu $L i^{1}$, Yameng $L i^{1}$, Gao Lei ${ }^{2}$, Liangliang $L i^{2}$, Xin Yang ${ }^{1}$, Zhilong Zhang ${ }^{2}$ \\ and Wenling Yang ${ }^{2 *}$ \\ ${ }^{1}$ Key Laboratory of New Materials and Facilities for Rural Renewable Energy (Ministry of Agriculture and Rural Affairs of China), \\ Henan Agricultural University, Zhengzhou, China, ${ }^{2}$ Key Laboratory of Microbial Engineering at the Institute of Biology, Henan \\ Academy of Sciences, Zhengzhou, China
}

Lead $(\mathrm{Pb})$-contaminated wastewater is the most common source of heavy metal ion pollution. In this study, agricultural waste edible fungi residue (EFR) was used to adsorb $\mathrm{Pb}(\mathrm{Il})$ ions in wastewater as a strategy to reduce environmental pollution and minimize poisoning by $\mathrm{Pb}$. The influence of $\mathrm{Pb}$ (II) concentration, solution $\mathrm{pH}$, and EFR concentration on the removal efficiency $(\mathrm{R})$ of $\mathrm{Pb}(\mathrm{II})$ was investigated with single factor design and response surface analysis. The maximum predicted $\mathrm{R}$ for $\mathrm{Pb}$ (II) was $76.34 \%$ under optimal conditions of $\mathrm{Pb}$ (II) concentration of $483.83 \mathrm{mg} / \mathrm{L}$, EFR concentration of $4.99 \mathrm{~g} / \mathrm{L}$, and $\mathrm{pH}$ of 5.89. The actual experimental value of $\mathrm{R}$ reached $76.97 \%$ under these conditions. The competition of $\mathrm{Pb}$ (II) ions for the available adsorption sites on EFR limited the maximum $\mathrm{R}$. A comparison of Fourier transform infrared spectroscopy before and after the adsorption of $\mathrm{Pb}(\mathrm{II})$, indicated that the functional groups of EFR significantly affected the effect of adsorption of heavy metals, and that the adsorption process was primarily affected by functional groups in the range of wavenumbers from 500 to $2,000 \mathrm{~cm}^{-1}$.

Keywords: edible fungi residue, adsorption mechanism, removal efficiency, $\mathrm{Pb}(\mathrm{II})$, optimization

\section{INTRODUCTION}

With the rapid progress of industrialization and the intensification of agricultural development, increasing amounts of heavy metal pollution have become a growing threat toward water and soil (Zhu et al., 2020). Owing to the complexity of its formation, concealment, and irreversibility, heavy metal pollution in water and soil cannot be easily remediated in nature and is difficult to treat $\mathrm{Hu}$ et al., 2015; Oliveira et al., 2019). The problem of water pollution caused by heavy metals is becoming increasingly prominent, and has become a widespread environmental problem.

Among the heavy metal ions, lead $(\mathrm{Pb})$ is considered to be one of the most common contaminants owing to its many uses in industry. In addition, $\mathrm{Pb}$ can be enriched and accumulated in crops and aquatic organisms (Jamali et al., 2009), enabling it to enter the human body through the food chain. $\mathrm{Pb}$ causes a series of effects on plant physiology and biochemistry when it enters the plant roots, stems, and leaves. Long-term exposure to $\mathrm{Pb}$ is known to pose a serious threat to human health owing to carcinogenesis, teratogenesis, and mutation (Wendt and Lee, 2010). Because of this, there is an urgent need to explore effective methods to remediate $\mathrm{Pb}$ pollution from wastewater.

The methods to treat heavy metal wastewater primarily include ion exchange, chemical precipitation, electrochemical methods, membrane filtration, and adsorption. The adsorption method for treating heavy metals in wastewater and soil can be operated conveniently, and has a wide range of application prospects (Mia et al., 2017). A variety of adsorbents including graphene oxide (Nguyen-Phan et al., 2011), $\mathrm{Ca}(\mathrm{OH})_{2}, \mathrm{Al}_{2} \mathrm{O}_{3}, \mathrm{SiO}_{2}, \mathrm{Fe}_{2} \mathrm{O}_{3}$, and other mineral oxides (Kuo et al., 
2011; Zhang K. et al., 2016; Zhang and Liu, 2019) have been used to remove heavy metals from wastewater. However, most of the currently used materials are inefficient, expensive, and can cause secondary pollution. Thus, there is a pressing need for new materials that can remove $\mathrm{Pb}$ from wastewater. The use of agricultural wastes as adsorbents not only allows for sustainable waste utilization, but also helps to remove toxic heavy metal ions in wastewater (Jin et al., 2018; Liu et al., 2018; Jin et al., 2021; Zhang et al., 2021). The use of waste biomass materials, including cotton stalks and grapefruit peels (Trakal et al., 2016; Fu et al., 2021), as precursors to process various activated carbon adsorbents to remove toxic heavy metals from wastewater is an active area of research.

Edible fungi residue (EFR) is a type of base waste from the cultivation of edible fungus, and it is one of the biomass raw materials that is the subject of study. More than 4 million tons of EFR are produced in China each year, but most is discarded or burned. Only $33 \%$ of this waste is utilized. The random disposal of EFR leads to the breeding of mold and pests and increases the number of harmful spores in the air, in addition to causing an enormous waste of resources and serving as a source of environmental pollution. Combustion can only capture approximately $10 \%$ of the heat energy. Thus, combustion is an unreasonable use for EFR biomass. EFR has loose and porous physical properties and is rich in sugars, organic acids, enzymes, and related bioactive ingredients (Jin et al., 2020; Wei et al., 2020). Study on the regeneration and comprehensive utilization of EFR has attracted a substantial amount of research interest (Wu et al., 2019).

Currently, the comprehensive utilization of EFR primarily focuses on animal feed, plant nutrients, and the extraction of organic bioactive substances, whereas the studier on EFR in the field of environmental pollution remediation mostly focus on the degradation of organic pollutants such as polycyclic aromatic hydrocarbons (PAHs) (Liu et al., 2019; Zhou et al., 2020) and aflatoxins (Hultberg et al., 2020; Norlia et al., 2020). The mechanism of action of EFR on heavy metals is complex, and its ability to remediate soil pollution varies with the soil texture, degree of heavy metal pollution, plant diversity, and planting regimes (Jiang et al., 2012; Ok et al., 2011). Steinbeiss et al. (2009) found that EFR can reduce the bulk density of soil, increase its water holding capacity, and affect the number and activity of soil microorganisms, thus, alleviating the toxicity of heavy metals to plants and promoting plant growth (Qin et al., 2019; Walker et al., 2004). Han et al. (2020) used EFR as a modifier to significantly improve the physicochemical properties of lead-zinc tailings; and found that it reduced the content of lead-and zinc in the soil and increased the concentration of biomass and chlorophyll of Paulownia fortunei. Moreover, the addition of EFR enhanced the binding between amino acids and heavy metals, increased the hydroxyl spectral content at $3,420 \mathrm{~cm}^{-1}$, and reduced the damage of free radicals to plant cells. EFR has also been founded to change the existing form of $\mathrm{Pb}$ in wastewater through adsorption, complexation, ion exchange, redox reaction, and surface precipitation (Hazrati et al., 2020). However, there are very few studies on the treatment of wastewater that contains $\mathrm{Pb}$ with $\mathrm{EFR}$, and the mechanism of interaction between EFR and heavy metals remains unclear. In this study, the characteristics of EFR and the adsorption of $\mathrm{Pb}(\mathrm{II})$ were analyzed, and the removal of $\mathrm{Pb}$ was optimized by determining the response surface.

\section{MATERIALS AND METHODS}

\section{Characteristics of EFR}

The EFR materials originate from waste fungal sticks after the cultivation of edible fungi. Fungal sticks are composed of $80-85 \%$ of the hardwood of broadleaf trees, such as willow, basswood, or elm, $12-17 \%$ wheat bran, and $0.8-1.2 \%$ sugar. An elemental analyzer (Elementar Vario El Cube; Elementar Analysensysteme GmbH, Hanou, Germany) was used to determine the elemental composition of EFR that had been naturally air-dried, crushed, and passed through 80 mesh sieves. The carrier gases were $\mathrm{O}_{2}$ and $\mathrm{N}_{2}$, and the air pressure was 0.2 and $0.12 \mathrm{MPa}$, respectively. The temperature for decomposition was $950-1,200^{\circ} \mathrm{C}$. The mass percentages of $\mathrm{C}$, $\mathrm{H}$ and $\mathrm{N}$ in the EFR were $33.900 \pm 0.215,4.779 \pm 0.001$, and $0.945 \pm 0.015 \%$, respectively. The content of $S$ was only $0.353 \pm 0.043 \%$.

The specific surface area of EFR was determined by a specific instrument to measure the surface area (BELSORP-mini; BEL, Osaka, Japan), which used $\mathrm{N}_{2}$ and $\mathrm{He}$ as carrier gases. The total pore volume and specific surface area of EFR were $3.3619 \times$ $10^{-4} \mathrm{~cm}^{3} / \mathrm{g}$ and $3.6858 \times 10^{-1} \mathrm{~m}^{2} / \mathrm{g}$, respectively. The average pore diameter of EFR was $3.6485 \mathrm{~nm}$.

\section{Thermo-Gravimetric Analysis}

Thermo-gravimetric (TG) and derivative thermo-gravimetric (DTG) curves were obtained at $0.1 \mathrm{mg}$ resolution using an SDT605 thermal analyzer (TA Instruments, New Castle, DE, United States). The furnace was purged with $\mathrm{N}_{2}$ for $30 \mathrm{~min}$ before it was used to establish an inert environment. A total of $50 \mathrm{ml} \mathrm{min}{ }^{-1}$ (99.5\% nitrogen, $0.5 \%$ oxygen) high purity flow of $\mathrm{N}_{2}$ was used in the experiment. The temperature was increased from room temperature to $600^{\circ} \mathrm{C}$ at a rate of $10^{\circ} \mathrm{C} \mathrm{min}^{-1}$ in the $\mathrm{N}_{2}$ atmosphere.

\section{Fourier Transform Infrared Spectroscopy}

The molecular groups of EFR were characterized by an IR906 Fourier-transform infrared spectroscopy (FTIR) (Ruian Technology Co., Ltd, Tianjin, China). Solid potassium bromide was ground to fine particles under a fluorescent lamp, pressed on a tablet press, and scanned for the background spectrum to eliminate the interference peak error that occurs during the measurement process. After setting the sample information, the EFR was placed in the infrared ray light path for scanning. The scanning range was $4,000-400 \mathrm{~cm}^{-1}$, and the resolution was $0.5 \mathrm{~cm}^{-1}$.

\section{Preparation of $\mathrm{Pb}$ (II) Solutions}

A $\mathrm{Pb}$ (II) stock solution $(1,000 \mathrm{mg} / \mathrm{L})$ was prepared using $\mathrm{Pb}\left(\mathrm{CH}_{3} \mathrm{COO}\right)_{2} \cdot 3 \mathrm{H}_{2} \mathrm{O}$. The $\mathrm{Pb}(\mathrm{II})$ working solutions were 
TABLE 1 | Variables value design of response surface.

\begin{tabular}{llcccc}
\hline Code & Variables & Unit & Low level & High level & Average \\
\cline { 4 - 6 } & & & $(\mathbf{- 1 )}$ & $\mathbf{( + 1 )}$ & $\mathbf{( 0 )}$ \\
\hline$A$ & $\mathrm{~Pb}(\mathrm{II})$ concentration & $\mathrm{mg} / \mathrm{L}$ & 400 & 600 & 500 \\
$B$ & $\mathrm{PH}$ value & & 5 & 7 & 6 \\
$C$ & EFR concentration & $\mathrm{g} / \mathrm{L}$ & 2 & 6 & 4
\end{tabular}

obtained by dilution of the $\mathrm{Pb}$ (II) stock solution. The $\mathrm{pH}$ value was adjusted by adding $\mathrm{HCl}$ or $\mathrm{NaOH}$ and measured with a digital pH meter (China FE28).

\section{Adsorption Experiments}

All the batch experiments were conducted in triangle bottles at $25 \pm 2^{\circ} \mathrm{C}$. In each triangle bottle, a specified amount of EFR was mixed with a fixed concentration of $\mathrm{Pb}$ (II) solution in a shaking table, which was operated at $150 \mathrm{rpm}$. The main parameters that affect adsorption were varied, including $\mathrm{Pb}$ (II) concentration $(100-1,000 \mathrm{mg} / \mathrm{L}), \quad \mathrm{pH} \quad(3-7)$, EFR concentration $(0.5-6 \mathrm{~g} / \mathrm{L})$, and contact time (10-960 min). The aqueous solution was filtered through a 0.45 -micron pore diameter filter membrane at a predetermined time for adsorption to take place. The filtered aqueous solution was subsequently sampled by the removal of $5 \mathrm{ml}$ with a syringe for analysis. The initial and residual concentrations of $\mathrm{Pb}$ (II) were determined by an AA-6880F/AAC type atomic absorption spectrophotometer (Shimadzu, Tokyo, Japan) with a wavelength accuracy of $\pm 0.3 \mathrm{~nm}$. The removal efficiency ( $R$ \%) was determined using Eq. 1 (Al-Jubouri et al., 2016; Alhassani et al., 2020). Each step of the experiment was conducted in triplicate.

$$
R \%=\frac{C_{0}-C_{\mathrm{e}}}{C_{0}} \times 100
$$

$\mathrm{C}_{0}: \mathrm{Pb}(\mathrm{II})$ concentrations before adsorption $(\mathrm{mg} / \mathrm{L})$.

$\mathrm{C}_{\mathrm{e}}: \mathrm{Pb}(\mathrm{II})$ concentrations after adsorption $(\mathrm{mg} / \mathrm{L})$.

\section{Experimental Design and Optimization}

The conditions for the removal of $\mathrm{Pb}$ (II)were optimized at $25 \pm$ $2^{\circ} \mathrm{C}$ and a contact time of $240 \mathrm{~min}$ with different initial concentrations of $\mathrm{Pb}(\mathrm{II})$ solutions, different $\mathrm{pH}$ values, and various doses of adsorbent (EFR). All the key significant factors were prepared in three levels: -1 for the low level, +1 for the high level, and 0 for the average level (Table 1) (Jing et al., 2020).

Each sample was agitated in a shaker until equilibrium was reached and then filtered. The concentration of heavy metal in the solution was determined using an atomic absorption spectrophotometer. The efficiency of $\mathrm{Pb}(\mathrm{II})$ removal was calculated using Eq. 1. After that, a regression analysis was conducted based on the data obtained to establish an empirical model, which was related to the response measured for the independent variables. The model equation is represented as Eq. 2:

$$
Y=C_{0}+\sum C_{i} X_{i}+\sum C_{i} X_{i}^{2}+\sum C_{i j} X_{i} X_{j}
$$

where $Y$ is the predicted response, $C_{0}$ is the intercept, $C i$ is the linear coefficient, and $\mathrm{Cij}$ is the interaction coefficient. Threedimensional response surface curves were drawn using Design Expert 8.0 software to study the interaction between different factors after analysis of variance (ANOVA) (Lu et al., 2016; Lu et al., 2019).

\section{RESULTS AND DISCUSSION}

\section{Thermal Decomposition Process of EFR}

The thermal gravimetric analysis are shown in Figure 1. The mass loss of EFR was similar to that of biomass straw. The ranges of temperature under $100^{\circ} \mathrm{C}$ acted as the drying step, during which most of the moisture turned into steam and escaped from the EFR. The levels of moisture were not considered in the kinetic analysis. The small loss of mass of EFR occurred between 100 and $170^{\circ} \mathrm{C}$, which could be owing to the loss of small amounts of moisture and light volatiles (Munir et al., 2009). Most of the mass loss occurred between 170 and $400^{\circ} \mathrm{C}$, which was related to the degradation of hemicellulose, cellulose, and lignin in sequence (TranVan et al., 2014; Yang et al., 2006). There was an obvious DTG peak at approximately $350^{\circ} \mathrm{C}$, which was primarily caused by the intense thermal decomposition of cellulose. This was different from the pyrolysis of corn stover, and cotton, sorghum, and soybean stalks in which the distinct DTG peak was readily apparent between 311 and $330^{\circ} \mathrm{C}$ (Zhang Z. et al., 2016). The temperature corresponded to the distinct DTG peak of EFR, which was higher than that of the biomass straw. This is owing to the fungal sticks of cultivated edible fungi, which were composed of $80-85 \%$ hardwood from broadleaf trees. This resulted in more lignin that surrounded the cellulose. The cellulose decomposition of EFR was still more difficult than that of biomass straw, although the content of organic matter was lower compared with the fungal sticks of uncultivated edible fungi, since the original wooden structure of EFR had undergone major

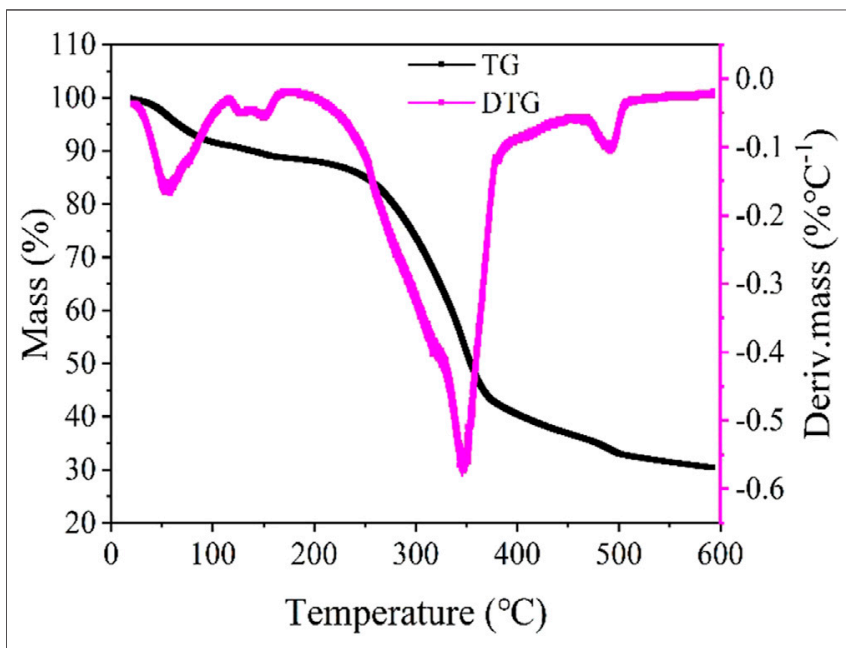

FIGURE 1 | TG analysis curves for EFR 


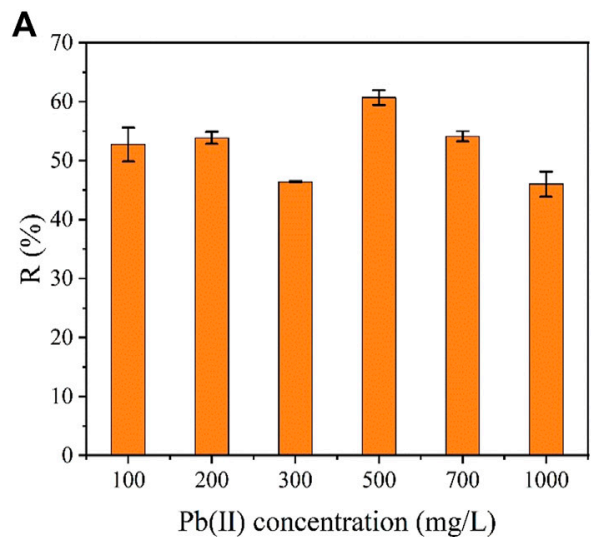

C

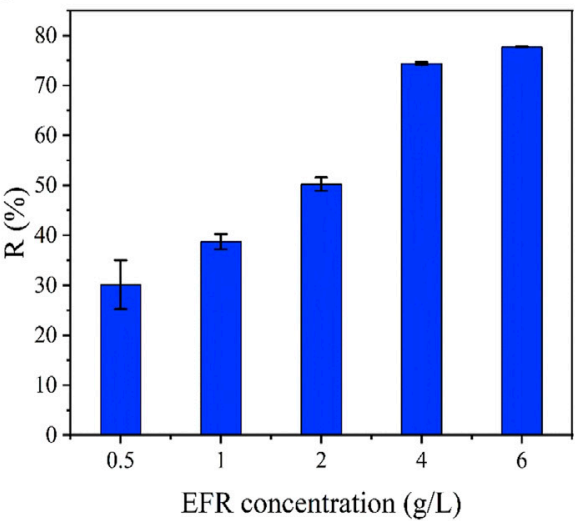

B

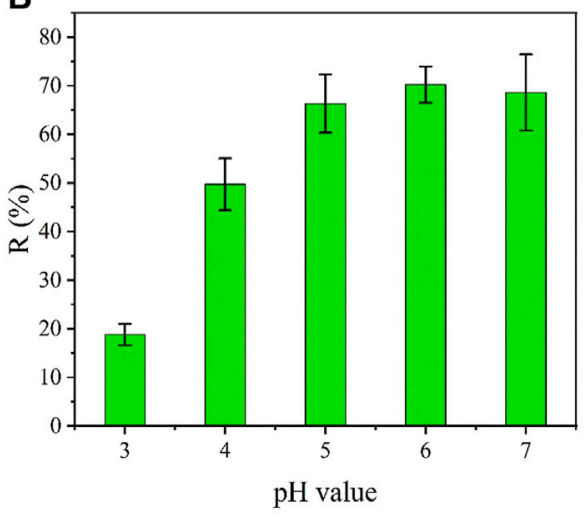

D

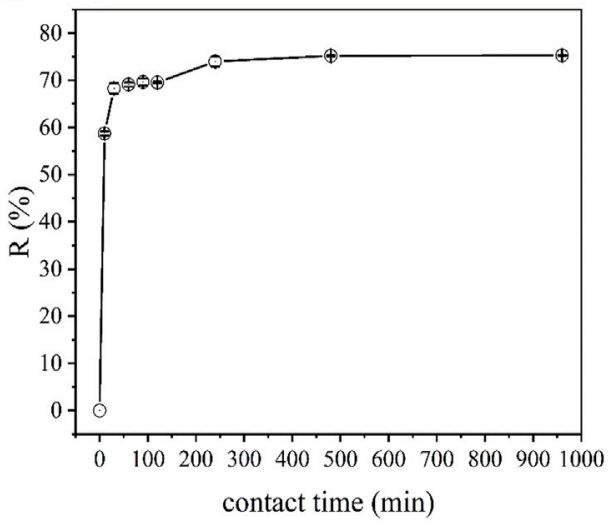

FIGURE 2 | $\mathrm{R}$ of $\mathrm{Pb}(\mathrm{II})$ at different $\mathrm{Pb}(\mathrm{II})$ concentration (A), values of $\mathrm{pH}$ (B), EFR concentration (C), and contact time (D).

changes owing to the continual decomposition of bacteria, archaea, and fungi that used it as nutrients. This primarily led to a looser internal structure and higher porosity, more specifically, a larger specific surface area. At the final stage of $400-600^{\circ} \mathrm{C}$, the passive pyrolysis stage, was a slow decomposition process, comparable to "tail" in all curves. In the final stage, the residues were carbonized into stable and complex organic material, that primarily consisted of ash and fixed carbon.

\section{Adsorption of $\mathbf{P b}$ (II) at Different Conditions}

The $\mathrm{R}$ of $\mathrm{Pb}$ (II) was investigated at different operation conditions. Figure 2A shows the effect of the concentration of $\mathrm{Pb}$ (II) on $\mathrm{R}$ over a range of $\mathrm{Pb}$ (II) concentrations $100-1,000 \mathrm{mg} / \mathrm{L}$. This experiment was conducted at a $\mathrm{pH}$ of 5 , EFR concentration of $4 \mathrm{~g} / \mathrm{L}$, mixing speed of $150 \mathrm{rpm}$, contact time of $960 \mathrm{~min}$, and temperature of $25 \pm$ $2^{\circ} \mathrm{C}$. The highest $\mathrm{R}$ value of $60.68 \%$ was detected at $500 \mathrm{mg} / \mathrm{L} \mathrm{Pb}(\mathrm{II})$ (Figure 2A). An increase in the concentrations resulted in a decrease of $\mathrm{R}$. This can be explained by the fact that there were a limited number of adsorption sites on the surface of the EFR adsorbent. As the concentration of pollutant ions in the aqueous solution increased, the competition for these ions to occupy available adsorption sites intensified (Han et al., 2010; Sajjadi et al., 2019). Thus, the R decreased. Overall, a concentration of $500 \mathrm{mg} / \mathrm{L} \mathrm{Pb}(\mathrm{II})$ was selected as the best value for subsequent experiments.
Figure 2B displays the influence of $\mathrm{pH}$ on the $\mathrm{R}$ of EFR over a range of $3-7$, while fixing other variables as follows: $\mathrm{Pb}$ (II) concentration of $500 \mathrm{mg} / \mathrm{L}$, EFR concentration of $4 \mathrm{~g} / \mathrm{L}$, mixing speed of $150 \mathrm{rpm}$, contact time of $960 \mathrm{~min}$, and a temperature of $25 \pm 2^{\circ} \mathrm{C}$. When the solution was acidic, there was significant effect on the $\mathrm{R}$ of $\mathrm{Pb}$ (II). $\mathrm{R}$ initially increased with an increase in the $\mathrm{pH}$, but then $\mathrm{R}$ decreased as the $\mathrm{pH}$ in solution increased. A maximum $\mathrm{R}$ of $70.22 \%$ was obtained at $\mathrm{pH}$. When the $\mathrm{pH}$ value of the solution was lower or higher than 6 , the $\mathrm{R}$ decreased. This phenomenon can be explained by the charge of EFR and the pollutant. When the $\mathrm{pH}$ of solution is < $\mathrm{pH}_{\mathrm{pzc}}$, the surface of the adsorbent would be positively charged. This facilitates electrostatic repulsion between the positively charged surface of the metal ion and EFR adsorbents (Yusuff et al., 2021).

Figure 2C shows the $\mathrm{R}$ of $\mathrm{Pb}(\mathrm{II})$ as a function of $\mathrm{EFR}$ concentration when it varied from 0.5 to $6 \mathrm{mg} / \mathrm{L}$. The other conditions were fixed as the follows: $\mathrm{Pb}$ (II) concentration of $500 \mathrm{mg} / \mathrm{L}, \mathrm{pH}$ of 6 , mixing speed of $150 \mathrm{rpm}$, contact time of $960 \mathrm{~min}$, and temperature of $25 \pm 2{ }^{\circ} \mathrm{C}$. $\mathrm{R}$ was founded to range from 30.11 to $76.75 \%$, as the EFR concentrations increased from 0.5 to $6 \mathrm{~g} / \mathrm{L}$. This result originates from an increase in EFR concentration, which indicated that there were more available adsorption sites (Nasseh et al., 2017). The contact time determines the rate of removal and the time that was required to reach the equilibrium status. Figure 2D shows the effect of contact time on the $\mathrm{R}$ of $\mathrm{Pb}$ (II) at $\mathrm{Pb}$ (II) concentration of $500 \mathrm{mg} / \mathrm{L}$, $\mathrm{pH}$ of 6 , mixing speed of $150 \mathrm{rpm}$, 
TABLE 2 | Box-Behnken experimental design with three independent variables.

\begin{tabular}{|c|c|c|c|c|c|c|c|}
\hline \multirow[t]{2}{*}{ Code } & \multicolumn{2}{|c|}{$\begin{array}{c}\mathrm{Pb}(\mathrm{II}) \text { concentration } \\
(\mathrm{mg} / \mathrm{L})\end{array}$} & \multicolumn{2}{|c|}{ pH } & \multicolumn{2}{|c|}{ EFR concentration (g/L) } & \multirow[t]{2}{*}{$\mathbf{R}(\%)$} \\
\hline & $A$ & Code & $B$ & Code & $c$ & Code & \\
\hline 1 & 500 & 0 & 5 & -1 & 2 & -1 & 46.23 \\
\hline 2 & 500 & 0 & 6 & 0 & 4 & 0 & 70.43 \\
\hline 3 & 400 & -1 & 6 & 0 & 2 & -1 & 52.96 \\
\hline 4 & 500 & 0 & 6 & 0 & 4 & 0 & 72.80 \\
\hline 5 & 600 & +1 & 7 & +1 & 4 & 0 & 64.57 \\
\hline 6 & 600 & +1 & 6 & 0 & 6 & +1 & 70.10 \\
\hline 7 & 500 & 0 & 6 & 0 & 4 & 0 & 77.05 \\
\hline 8 & 400 & -1 & 6 & 0 & 6 & +1 & 70.05 \\
\hline 9 & 500 & 0 & 5 & -1 & 6 & +1 & 73.59 \\
\hline 10 & 600 & +1 & 5 & -1 & 4 & 0 & 61.03 \\
\hline 11 & 400 & -1 & 7 & +1 & 4 & 0 & 72.27 \\
\hline 12 & 600 & +1 & 6 & 0 & 2 & -1 & 39.29 \\
\hline 13 & 500 & 0 & 6 & 0 & 4 & 0 & 72.46 \\
\hline 14 & 500 & 0 & 7 & +1 & 6 & +1 & 64.55 \\
\hline 15 & 400 & -1 & 5 & -1 & 4 & 0 & 65.04 \\
\hline 16 & 500 & 0 & 7 & +1 & 2 & -1 & 51.38 \\
\hline 17 & 500 & 0 & 6 & 0 & 4 & 0 & 74.26 \\
\hline
\end{tabular}

TABLE 3 | ANOVA for adsorption of $\mathrm{Pb}$ (II).

\begin{tabular}{|c|c|c|c|c|c|}
\hline Source & Sum of squares & Degree freedom & Mean square & F-value & $p$-value \\
\hline$A$ & 80.14 & 1 & 80.14 & 9.64 & 0.0172 \\
\hline$B$ & 5.90 & 1 & 5.90 & 0.7094 & 0.4275 \\
\hline$A B$ & 3.42 & 1 & 3.42 & 0.4109 & 0.5419 \\
\hline$A C$ & 47.08 & 1 & 47.08 & 5.66 & 0.0489 \\
\hline$B C$ & 50.31 & 1 & 50.31 & 6.05 & 0.0435 \\
\hline$C^{2}$ & 513.55 & 1 & 513.55 & 61.75 & 0.0001 \\
\hline Residual & 58.21 & 7 & 8.32 & & \\
\hline Lack of Fit & 34.11 & 3 & 11.37 & 1.89 & 0.273 \\
\hline Pure Error & 24.11 & 4 & 6.03 & & \\
\hline Cor Total & 1912.38 & 16 & & & \\
\hline
\end{tabular}

Coefficient of determination $\left(R^{2}\right)=0.9696$

EFR concentration of $4 \mathrm{~g} / \mathrm{L}$, and temperature of $25 \pm 2^{\circ} \mathrm{C}$. The $\mathrm{R}$ increased quickly within the first $30 \mathrm{~min}$, reached $68.28 \%$, and then slowly increased. The equilibrium state occurred within the first 240 min of contact time, but the $\mathrm{R}$ value of the equilibrium state was slightly higher than $74.01 \%$. Therefore, a contact time of $240 \mathrm{~min}$ was found to be more suitable for the additional adsorption studies. Part of the organic matter is decomposed and utilized during the cultivation of edible fungi, resulting in a larger specific surface area $\left(3.6858 \times 10^{-1} \mathrm{~m}^{2} / \mathrm{g}\right)$ of the waste fungal residue, which is conducive to the removal of heavy metals.

\section{Analysis of Removal Efficiency With Response Surface}

A Box-Behnken experimental design (BBD) was used to perform multiple regression analysis. The quadratic polynomial Eq. 3 for the coded values and Eq. 4 for the actual experimental values as a function of variables $A(\mathrm{~Pb}$ [II] concentration), $B(\mathrm{pH}), C$ (EFR concentration). The function of these variables was chosen because they had a large effect on the amount of $\mathrm{Pb}(\mathrm{II})$ adsorbed as demonstrated by the single variable experiment results. The responses obtained at different experimental runs are shown in Table 2.

$$
\begin{aligned}
Y_{\text {Coded }}= & 73.40-3.17 A+0.8587 B+11.05 C-0.9243 A B \\
& +3.43 A C-3.55 B C-4.26 A^{2}-3.42 B^{2}-11.04 C^{2} \\
Y_{\text {Actual }}= & -247.73593+0.380974 A+53.60653 B+29.67834 C \\
& -0.009243 A B+0.017153 A C-1.77329 B C \\
& -0.000426 A^{2}-3.41942 B^{2}-2.76097 C^{2}
\end{aligned}
$$



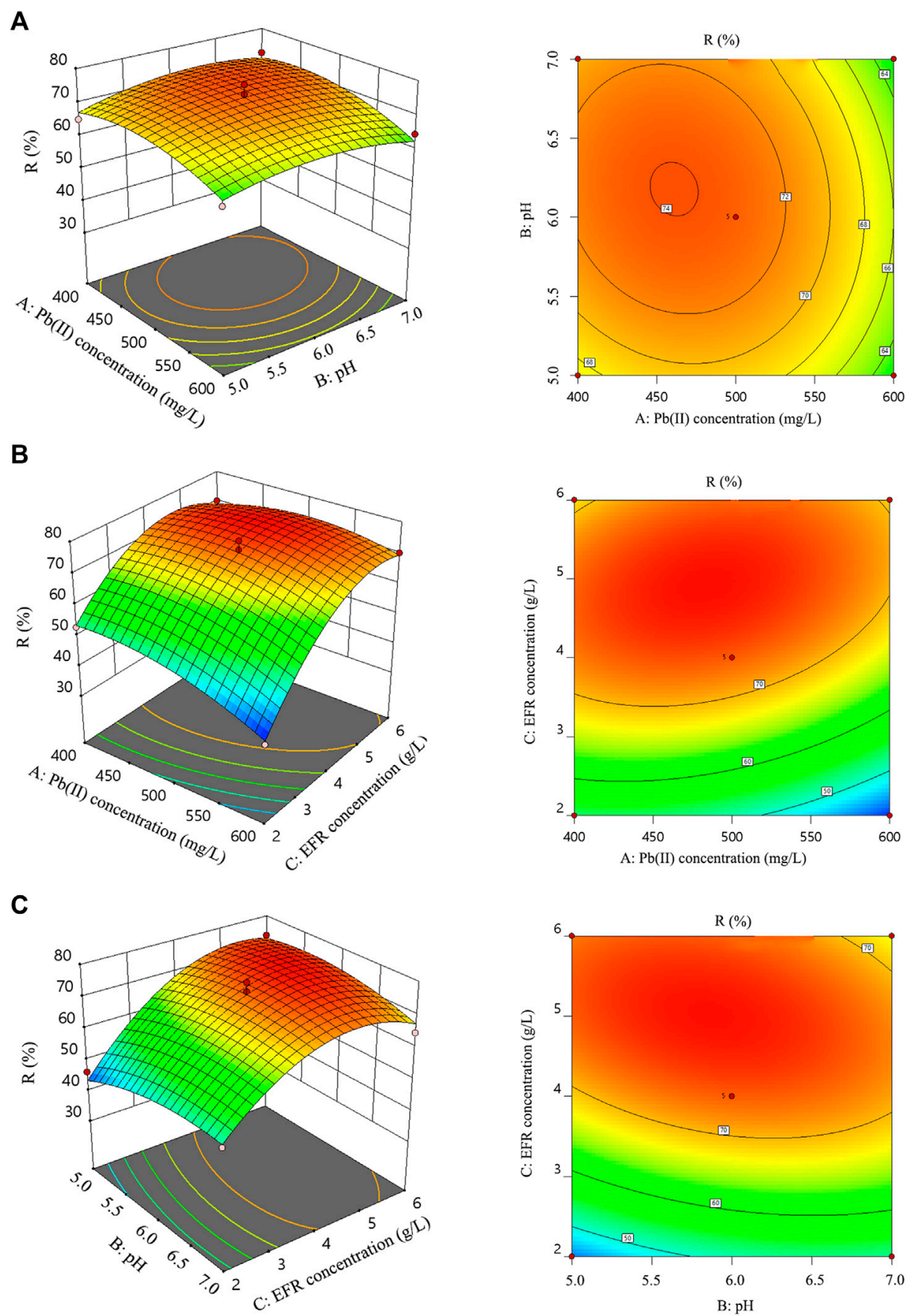

FIGURE 3 | The two- and three-dimensional model for $\mathrm{Pb}(\mathrm{II})$ adsorption by EFR. The response surface model was obtained by the BBD design with the data shown in Table 2. (A): $\mathrm{R}$ of $\mathrm{Pb}$ (II) as a function of $\mathrm{Pb}$ (II) concentration and $\mathrm{pH}$ value; (B): $\mathrm{R}$ of $\mathrm{Pb}$ (II) as a function of $\mathrm{Pb}$ (II) concentration and $\mathrm{EFR}$ concentration; (C): $\mathrm{R}$ of $\mathrm{Pb}$ (II) as a function of $\mathrm{pH}$ value and EFR concentration.

The analysis of variance (ANOVA) is shown in Table 3. The $p$ value of the lack-of-fit was not significant $(0.273>0.05)$, indicating that the responses were acceptable for use in this model. The model's $p$-values $=0.0002<0.05$ indicates the model was significant and fitted well into the experimental data. The $R^{2}$ value of 0.9696 suggested that the model could effectively predict the results of adsorption experiments. Table 3 reveals that the linear term of $\mathrm{Pb}$ (II) concentration and EFR concentration had a significant effect on $\mathrm{R}$, and the quadratic term of $\mathrm{Pb}(\mathrm{II})$ concentration $\left(A^{2}\right), \mathrm{pH} \quad\left(B^{2}\right)$, and EFR concentration $\left(C^{2}\right)$ showed a significant effect on $\mathrm{R}(p<0.05)$. A significant interaction between the $\mathrm{Pb}(\mathrm{II})$ concentration and EFR concentration $(A C)$ was observed $(p<0.05)$, along with significance in the interaction between $\mathrm{pH}$ and EFR 
concentration $(B C)(p<0.05)$. This study that was subsequently used to optimize the conditions predicted a maximum $\mathrm{R}$ of $\mathrm{Pb}$ (II) of $76.34 \%$, with the optimal conditions of $\mathrm{Pb}(\mathrm{II})$ concentration of $483.83 \mathrm{mg} / \mathrm{L}, \mathrm{pH}$ of 5.89 , and EFR concentration of $4.99 \mathrm{~g} / \mathrm{L}$.

Figure 3 shows the three-dimensional response surface and contour plot for $\mathrm{R}$ as function of $\mathrm{Pb}$ (II) concentration, EFR concentration, and $\mathrm{pH}$. The response surface of the model was plotted by maintaining one variable unchanged at the central level and varying the other two variables within the experimental range (Lu et al., 2016; Lu C. et al., 2020; Lu C. Y. et al., 2020). The significance and interactions between the variables were identified through the color and shape of contour plots; An example of this type of analysis is the color of two- and threedimensional contour plots that changed from blue to red to visualize the change in removal efficiency from low to high. In addition, the contour lines are elliptical in shape, which indicates strong interactions between the two variables. There is no interaction when the contour lines are circular ( $\mathrm{Li}$ et al., 2017). Figure 3A illustrates the three-dimensional response surface and contour plot for $\mathrm{R}$ as function of the $\mathrm{Pb}$ (II) concentration and $\mathrm{pH}$, while maintaining a constant concentration of the EFR $(4 \mathrm{~g} / \mathrm{L})$. R continuously increased in parallel with the increase in $\mathrm{Pb}(\mathrm{II})$ concentrations and $\mathrm{pH}$ until it reached its peak, then decreased as the concentration of $\mathrm{Pb}$ (II) and the $\mathrm{pH}$ increased. This can be explained by the fact that a limited number of adsorption sites exist on the surface of the used adsorbent, and a $\mathrm{pH}$ that is too high or low would inhibit the adsorption properties of EFR. Moreover, the contour plots are circular, indicating that there was no significant interaction between the $\mathrm{Pb}(\mathrm{II})$ concentration and the $\mathrm{pH}$. This was also confirmed by the ANOVA results (Table 3; $p=0.5419$ ). Based the three-dimensional response surface plot and two-dimensional contour plot (Figures 3B,C), the interactive effects of $\mathrm{Pb}$ (II) concentration, EFR concentration and $\mathrm{pH}$ indicated that the concentration of EFR was significant. These results also provided additional confirmation of the ANOVA results (Table 3), in which the $p$-value of $\mathrm{Pb}$ (II) concentration and EFR concentration, and $\mathrm{pH}$ value and EFR concentration were 0.0489 and 0.0435 , respectively. The experimental result of $76.97 \%$ was obtained under the optimal conditions in the $\mathrm{Pb}$ (II) adsorption experiments, which was consistent with the predicted value $(76.34 \%)$ established from the model.

\section{Adsorbent Mechanism of EFR for Pb(II) lons}

In FTIR, infrared rays of different wavelengths are used to irradiate substance molecules. Some infrared rays of specific wavelengths are absorbed, leading to absorption peaks that appear at different wavelengths. Together, these form infrared spectra. Different absorption peaks correspond to varying bonds or functional groups. FTIR can be used to rapidly conduct qualitative and quantitative analysis to characterize the EFR adsorbent compared with $\mathrm{Pb}$ (II) ions. The FTIR spectra of the EFR before and after adsorption with $\mathrm{Pb}(\mathrm{II})$ under optimal removal conditions are shown in Figure 4. There was an obvious peak of absorption at $913 \mathrm{~cm}^{-1}$ for EFR, which is characteristic for the functional group C-O stretch of cellulose, semi-fiber, and lignin (Zhang et al., 2007; Liu et al., 2008). The

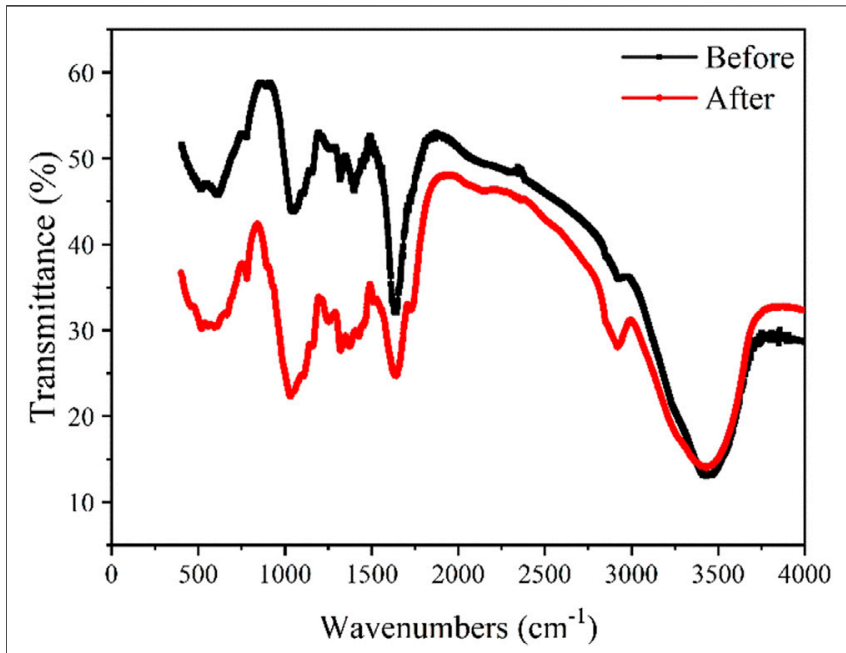

FIGURE 4 | FTIR patterns of EFR before and after reaction with $\mathrm{Pb}(\mathrm{II})$ ions.

C-O bond of EFR moved from the original 913 to $842 \mathrm{~cm}^{-1}$ after adsorption with $\mathrm{Pb}(\mathrm{II})$, resulting in a $71 \mathrm{~cm}^{-1}$ movement. Several strong peaks were detected before the EFR was adsorbed; The peaks at $1,194,1,491,1,979$ and $3,845 \mathrm{~cm}^{-1}$ represent the C-CO$\mathrm{C}, \mathrm{C}-\mathrm{H}, \mathrm{C}=\mathrm{C}$, and $\mathrm{O}-\mathrm{H}$ stretches, respectively (Zhou et al., 2011). A comparison of these two FTIR patterns indicated that the number of peaks $\left(1,194,1,491\right.$, and $\left.1,979 \mathrm{~cm}^{-1}\right)$ significantly decreased. This is because these peaks, and therefore these functional groups, react with the $\mathrm{Pb}$ (II) ions during the adsorption process. Interestingly, there was no significant reduction at peak $3,845 \mathrm{~cm}^{-1}$. Taken together, this reveals that the adsorption process of $\mathrm{Pb}$ (II) ions to EFR was chemisorption, and the functional groups of EFR in the wavenumbers that range from 500 to $2,000 \mathrm{~cm}^{-1}$ were primarily responsible.

\section{CONCLUSION}

The active mechanism of edible fungi residue to adsorb $\mathrm{Pb}$ (II) ions was revealed using an elemental analyzer, an instrument that specifically measures surface area, and thermo-gravimetric and Fourier transform infrared spectroscopy analysis. The functional groups of edible fungi residue within a range of wavenumbers from 500 to $2,000 \mathrm{~cm}^{-1}$ are primarily responsible for the adsorption process. In addition, the behavior and efficiency of edible fungi residue toward the removal of $\mathrm{Pb}$ (II) in batch-mode experiments showed that the adsorption active sites on the surface of edible fungi residue improved the removal of $\mathrm{Pb}(\mathrm{II})$, and that the competition of $\mathrm{Pb}$ (II) ions to occupy the available adsorption sites on edible fungi residue were the limiting factor for its ability to serve as an adsorbent. Simultaneously, the response surface was used to optimize the removal of $\mathrm{Pb}(\mathrm{II})$. It was demonstrated that a Box-Behnken experimental design model could predict the removal of $\mathrm{Pb}(\mathrm{II})$, which effectively explained $96.96 \%$ of the variability in adsorption process. The maximum $\mathrm{R}$ of $\mathrm{Pb}$ (II) (76.34\%) was predicted, and experimentally verified. This 
study has shown that edible fungi residue can be used as an effective adsorbent to remove $\mathrm{Pb}$ (II) ions from wastewater.

\section{DATA AVAILABILITY STATEMENT}

The original contributions presented in the study are included in the article/supplementary material, further inquiries can be directed to the corresponding author.

\section{AUTHOR CONTRIBUTIONS}

The authors have contributed to this article as follows: Conceptualization, YJ and WY; Methodology, YJ and WY;

\section{REFERENCES}

Al-Jubouri, S. M., Curry, N. A., and Holmes, S. M. (2016). Hierarchical Porous Structured Zeolite Composite for Removal of Ionic Contaminants from Waste Streams and Effective Encapsulation of Hazardous Waste. J. Hazard. Mater. 320, 241-251. doi:10.1016/j.jhazmat.2016.08.011

Alhassani, M. H., Al-Jubouri, S. M., and Al-Jendeel, H. A. (2020). Stabilization of Phenol Trapped by Agricultural Waste: a Study of the Influence of Ambient Temperature on the Adsorbed Phenol. Dwt 187, 266-276. doi:10.5004/ dwt.2020.25411

Fu, Y., Yang, Z., Xia, Y., Xing, Y., and Gui, X. (2021). Adsorption of Ciprofloxacin Pollutants in Aqueous Solution Using Modified Waste Grapefruit Peel. Energy Sourc. A: Recovery, Utilization, Environ. Effects 43 (2), 225-234. doi:10.1080/ 15567036.2019.1624877

Han, L., Chen, Y., Chen, M., Wu, Y., Su, R., Du, L., et al. (2020). Mushroom Residue Modification Enhances Phytoremediation Potential of Paulownia Fortunei to lead-zinc Slag. Chemosphere 253, 126774. doi:10.1016/ j.chemosphere.2020.126774

Han, R., Zhang, L., Song, C., Zhang, M., Zhu, H., and Zhang, L. (2010). Characterization of Modified Wheat Straw, Kinetic and Equilibrium Study about Copper Ion and Methylene Blue Adsorption in Batch Mode. Carbohydr. Polym. 79 (4), 1140-1149. doi:10.1016/j.carbpol.2009.10.054

Hazrati, S., Farahbakhsh, M., Heydarpoor, G., and Besalatpour, A. A. (2020). Mitigation in Availability and Toxicity of Multi-Metal Contaminated Soil by Combining Soil Washing and Organic Amendments Stabilization. Ecotoxicology Environ. Saf. 201, 110807. doi:10.1016/j.ecoenv.2020.110807

Hu, R., Wang, X., Dai, S., Shao, D., Hayat, T., and Alsaedi, A. (2015). Application of Graphitic Carbon Nitride for the Removal of $\mathrm{Pb}(\mathrm{II})$ and Aniline from Aqueous Solutions. Chem. Eng. J. 260, 469-477. doi:10.1016/j.cej.2014.09.013

Hultberg, M., Ahrens, L., and Golovko, O. (2020). Use of Lignocellulosic Substrate Colonized by Oyster Mushroom (Pleurotus Ostreatus) for Removal of Organic Micropollutants from Water. J. Environ. Manage. 272, 111087. doi:10.1016/ j.jenvman.2020.111087

Jamali, M. K., Kazi, T. G., Arain, M. B., Afridi, H. I., Jalbani, N., Kandhro, G. A., et al. (2009). Heavy Metal Accumulation in Different Varieties of Wheat (Triticum aestivum L.) Grown in Soil Amended with Domestic Sewage Sludge. J. Hazard. Mater. 164 (2-3), 1386-1391. doi:10.1016/ j.jhazmat.2008.09.056

Jiang, J., Xu, R.-k., Jiang, T.-y., and Li, Z. (2012). Immobilization of $\mathrm{Cu}(\mathrm{II}), \mathrm{Pb}(\mathrm{II})$ and Cd(II) by the Addition of rice Straw Derived Biochar to a Simulated Polluted Ultisol. J. Hazard. Mater. 229-230, 145-150. doi:10.1016/ j.jhazmat.2012.05.086

Jin, Y., Teng, C., Yu, S., Song, T., Dong, L., Liang, J., et al. (2018). Batch and FixedBed Biosorption of Cd(II) from Aqueous Solution Using Immobilized Pleurotus Ostreatus Spent Substrate. Chemosphere 191, 799-808. doi:10.1016/ j.chemosphere.2017.08.154

Jin, Y., Zhang, M., Jin, Z., Wang, G., Li, R., Zhang, X., et al. (2021). Characterization of Biochars Derived from Various Spent Mushroom Substrates and Evaluation
Formal analysis, YJ; Writing-Original Draft, YJ; Investigation, ZL, GL, XY, and ZZ; Writing-Review and Editing, YL, LL, and WY; Funding acquisition, LL and WY. All authors have read and agreed to the published version of the article.

\section{FUNDING}

This research was funded by the National Natural Science Foundation of China (grant number 31800361), Project of Henan Academy of Sciences (grant numbers 200405006, 210605041) and Undergraduate Innovation and Entrepreneurship Training Program of Henan Province (grant number S202010466033).

of Their Adsorption Performance of $\mathrm{Cu}(\mathrm{II})$ Ions from Aqueous Solution. Environ. Res. 196, 110323. doi:10.1016/j.envres.2020.110323

Jin, Z., Zhang, M., Li, R., Zhang, X., Wang, G., Liu, X., et al. (2020). Spent Mushroom Substrate Combined with Alkaline Amendment Passivates Cadmium and Improves Soil Property. Environ. Sci. Pollut. Res. 27 (14), 16317-16325. doi:10.1007/s11356-020-08099-3

Jing, Y., Li, F., Li, Y., Jin, P., Zhu, S., He, C., et al. (2020). Statistical Optimization of Simultaneous Saccharification Fermentative Hydrogen Production from Corn stover. Bioengineered 11 (1), 428-438. doi:10.1080/21655979.2020.1739405

Kuo, J.-H., Lin, C.-L., and Wey, M.-Y. (2011). Effect of Particle Agglomeration on Heavy Metals Adsorption by Al- and Ca-Based Sorbents during Fluidized Bed Incineration. Fuel Process. Technology 92 (10), 2089-2098. doi:10.1016/ j.fuproc.2011.06.014

Li, Y., Zhang, Z., Jing, Y., Ge, X., Wang, Y., Lu, C., et al. (2017). Statistical Optimization of Simultaneous Saccharification Fermentative Hydrogen Production from Platanus Orientalis Leaves by Photosynthetic Bacteria HAU-M1. Int. J. Hydrogen Energ. 42 (9), 5804-5811. doi:10.1016/ j.ijhydene.2016.11.182

Liu, C. F., Sun, R. C., Qin, M. H., Zhang, A. P., Ren, J. L., Ye, J., et al. (2008) Succinoylation of Sugarcane Bagasse under Ultrasound Irradiation. Bioresour. Technology 99 (5), 1465-1473. doi:10.1016/j.biortech.2007.01.062

Liu, X., Ge, W., Zhang, X., Chai, C., Wu, J., Xiang, D., et al. (2019). Biodegradation of Aged Polycyclic Aromatic Hydrocarbons in Agricultural Soil by Paracoccus Sp. LXC Combined with Humic Acid and Spent Mushroom Substrate. J. Hazard. Mater. 379, 120820. doi:10.1016/j.jhazmat.2019.120820

Liu, X., Bai, X., Dong, L., Liang, J., Jin, Y., Wei, Y., et al. (2018). Composting Enhances the Removal of lead Ions in Aqueous Solution by Spent Mushroom Substrate: Biosorption and Precipitation. J. Clean. Prod. 200, 1-11. doi:10.1016/ j.jclepro.2018.07.182

Lu, C., Jing, Y., Zhang, H., Lee, D. J., Tahir, N., Zhang, Q., et al. (2020a). Biohydrogen Production through Active Saccharification and PhotoFermentation from Alfalfa. Bioresour. Technol. 304, 123007. doi:10.1016/ j.biortech.2020.123007

Lu, C. Y., Tahir, N., Li, W. Z., Zhang, Z. P., Jiang, D. P., Guo, S. Y., et al. (2020b). Enhanced Buffer Capacity of Fermentation Broth and Biohydrogen Production from Corn Stalk with $\mathrm{Na}_{2} \mathrm{HPO}_{4} / \mathrm{NaH}_{2} \mathrm{PO}_{4}$. Bioresour. Technology 313, 123783. doi:10.1016/j.biortech.2020.123783

Lu, C., Zhang, H., Zhang, Q., Tahir, N., Hu, J., He, C., et al. (2019). Optimization of Biohydrogen Production from Cornstalk through Surface Response Methodology. j biobased mat bioenergy 13 (6), 830-839. doi:10.1166/ jbmb.2019.1921

Lu, C., Zhang, Z., Ge, X., Wang, Y., Zhou, X., You, X., et al. (2016). Bio-hydrogen Production from Apple Waste by Photosynthetic Bacteria HAU-M1. Int. J. Hydrogen Energ. 41 (31), 13399-13407. doi:10.1016/j.ijhydene.2016.06.101

Mia, S., Dijkstra, F. A., and Singh, B. (2017). Aging Induced Changes in Biochar's Functionality and Adsorption Behavior for Phosphate and Ammonium. Environ. Sci. Technol. 51 (15), 8359-8367. doi:10.1021/acs.est.7b00647

Munir, S., Daood, S. S., Nimmo, W., Cunliffe, A. M., and Gibbs, B. M. (2009). Thermal Analysis and Devolatilization Kinetics of Cotton Stalk, Sugar Cane 
Bagasse and Shea Meal under Nitrogen and Air Atmospheres. Bioresour. Technology 100 (3), 1413-1418. doi:10.1016/j.biortech.2008.07.065

Nasseh, N., Taghavi, L., Barikbin, B., and Harifi-Mood, A. R. (2017). The Removal of $\mathrm{Cr}(\mathrm{VI})$ from Aqueous Solution by almond green hull Waste Material: Kinetic and Equilibrium Studies. J. Water Reuse Desalination 7 (4), 449-460. doi:10.2166/wrd.2016.047

Nguyen-Phan, T.-D., Pham, V. H., Shin, E. W., Pham, H.-D., Kim, S., Chung, J. S., et al. (2011). The Role of Graphene Oxide Content on the AdsorptionEnhanced Photocatalysis of Titanium Dioxide/graphene Oxide Composites. Chem. Eng. J. 170 (1), 226-232. doi:10.1016/j.cej.2011.03.060

Norlia, M., Jinap, S., Nor-Khaizura, M. A. R., Radu, S., John, J. M., Rahman, M. A. H., et al. (2020). Modelling the Effect of Temperature and Water Activity on the Growth Rate of Aspergillus flavus and Aflatoxin Production in Peanut Meal Extract agar. Int. J. Food Microbiol. 335, 108836. doi:10.1016/ j.ijfoodmicro.2020.108836

Ok, Y. S., Usman, A. R. A., Lee, S. S., Abd El-Azeem, S. A. M., Choi, B., Hashimoto, Y., et al. (2011). Effects of Rapeseed Residue on lead and Cadmium Availability and Uptake by rice Plants in Heavy Metal Contaminated Paddy Soil. Chemosphere 85 (4), 677-682. doi:10.1016/ j.chemosphere.2011.06.073

Oliveira, M. L. S., Izquierdo, M., Querol, X., Lieberman, R. N., Saikia, B. K., and Silva, L. F. O. (2019). Nanoparticles from Construction Wastes: A Problem to Health and the Environment. J. Clean. Prod. 219, 236-243. doi:10.1016/ j.jclepro.2019.02.096

Qin, J., Xiong, H., Ma, H., and Li, Z. (2019). Effects of Different Fertilizers on Residues of Oxytetracycline and Microbial Activity in Soil. Environ. Sci. Pollut. Res. 26 (1), 161-170. doi:10.1007/s11356-018-3603-9

Sajjadi, S.-A., Meknati, A., Lima, E. C., Dotto, G. L., Mendoza-Castillo, D. I., Anastopoulos, I., et al. (2019). A Novel Route for Preparation of Chemically Activated Carbon from Pistachio wood for Highly Efficient $\mathrm{Pb}$ (II) Sorption. J. Environ. Manage. 236, 34-44. doi:10.1016/j.jenvman.2019.01.087

Steinbeiss, S., Gleixner, G., and Antonietti, M. (2009). Effect of Biochar Amendment on Soil Carbon Balance and Soil Microbial Activity. Soil Biol. Biochem. 41 (6), 1301-1310. doi:10.1016/j.soilbio.2009.03.016

Trakal, L., Veselská, V., Šafařík, I., Vítková, M., Č́halová, S., and Komárek, M. (2016). Lead and Cadmium Sorption Mechanisms on Magnetically Modified Biochars. Bioresour. Technology 203, 318-324. doi:10.1016/ j.biortech.2015.12.056

TranVan, L., Legrand, V., and Jacquemin, F. (2014). Thermal Decomposition Kinetics of Balsa wood: Kinetics and Degradation Mechanisms Comparison between Dry and Moisturized Materials. Polym. Degrad. Stab. 110, 208-215. doi:10.1016/j.polymdegradstab.2014.09.004

Walker, D. J., Clemente, R., and Bernal, M. P. (2004). Contrasting Effects of Manure and Compost on Soil pH, Heavy Metal Availability and Growth of Chenopodium album L. In a Soil Contaminated by Pyritic Mine Waste. Chemosphere 57 (3), 215-224. doi:10.1016/j.chemosphere.2004.05.020

Wei, Y., Jin, Z., Zhang, M., Li, Y., Huang, S., Liu, X., et al. (2020). Impact of Spent Mushroom Substrate on Cd Immobilization and Soil Property. Environ. Sci. Pollut. Res. 27 (3), 3007-3022. doi:10.1007/s11356-019-07138-y

Wendt, J. O. L., and Lee, S. J. (2010). High-temperature Sorbents for $\mathrm{Hg}, \mathrm{Cd}, \mathrm{Pb}$, and Other Trace Metals: Mechanisms and Applications. Fuel 89 (4), 894-903. doi:10.1016/j.fuel.2009.01.028

Wu, Q., Xian, Y., He, Z., Zhang, Q., Wu, J., Yang, G., et al. (2019). Adsorption Characteristics of $\mathrm{Pb}(\mathrm{II})$ Using Biochar Derived from Spent Mushroom Substrate. Sci. Rep. 9, 15999. doi:10.1038/s41598-019-52554-2
Yang, H., Yan, R., Chen, H., Zheng, C., Lee, D. H., and Liang, D. T. (2006). In-depth Investigation of Biomass Pyrolysis Based on Three Major Components: Hemicellulose, Cellulose and Lignin. Energy Fuels 20 (1), 388-393. doi:10.1021/ef0580117

Yusuff, A. S., Owolabi, J. O., and Igbomezie, C. O. (2021). Optimization of Process Parameters for Adsorption of Heavy Metals from Aqueous Solutions by Alumina-Onion Skin Composite. Chem. Eng. Commun. 208 (1), 14-28. doi:10.1080/00986445.2019.1680371

Zhang, G. S., Liu, N., Luo, Y., Zhang, H. B., Su, L., Oh, K., et al. (2021). Efficient Removal of $\mathrm{Cu}(\mathrm{II}), \mathrm{Zn}(\mathrm{II})$, and $\mathrm{Cd}(\mathrm{II})$ from Aqueous Solutions by a mineralrich Biochar Derived from a Spent Mushroom (Agaricus Bisporus) Substrate. Materials 14 (1), 35. doi:10.3390/ma14010035

Zhang, K., Zhang, D., Zhang, K., and Cao, Y. (2016a). Capture of Gas-phase Arsenic by Ferrospheres Separated from Fly Ashes. Energy Fuels 30 (10), 8746-8752. doi:10.1021/acs.energyfuels.6b01637

Zhang, W., Liang, M., and Lu, C. (2007). Morphological and Structural Development of Hardwood Cellulose during Mechanochemical Pretreatment in Solid State through Pan-Milling. Cellulose 14 (5), 447-456. doi:10.1007/ s10570-007-9135-y

Zhang, Y., and Liu, J. (2019). Density Functional Theory Study of Arsenic Adsorption on the Fe2O3 (001) Surface. Energy Fuels 33 (2), 1414-1421. doi:10.1021/acs.energyfuels.8b04155

Zhang, Z., He, C., Sun, T., Zhang, Z., Song, K., Wu, Q., et al. (2016b). Thermophysical Properties of Pretreated Agricultural Residues for Bio-Hydrogen Production Using Thermo-Gravimetric Analysis. Int. J. Hydrogen Energ. 41 (10), 5234-5242. doi:10.1016/j.ijhydene.2016.01.079

Zhou, C., Wu, Q., Yue, Y., and Zhang, Q. (2011). Application of Rod-Shaped Cellulose Nanocrystals in Polyacrylamide Hydrogels. J. Colloid Interf. Sci. 353 (1), 116-123. doi:10.1016/j.jcis.2010.09.035

Zhou, J., Ge, W., Zhang, X., Wu, J., Chen, Q., Ma, D., et al. (2020). Effects of Spent Mushroom Substrate on the Dissipation of Polycyclic Aromatic Hydrocarbons in Agricultural Soil. Chemosphere 259, 127462. doi:10.1016/ j.chemosphere.2020.127462

Zhu, L., Tong, L., Zhao, N., Wang, X., Yang, X., and Lv, Y. (2020). Key Factors and Microscopic Mechanisms Controlling Adsorption of Cadmium by Surface Oxidized and Aminated Biochars. J. Hazard. Mater. 382, 121002. doi:10.1016/j.jhazmat.2019.121002

Conflict of Interest: The authors declare that the research was conducted in the absence of any commercial or financial relationships that could be construed as a potential conflict of interest.

Publisher's Note: All claims expressed in this article are solely those of the authors and do not necessarily represent those of their affiliated organizations, or those of the publisher, the editors and the reviewers. Any product that may be evaluated in this article, or claim that may be made by its manufacturer, is not guaranteed or endorsed by the publisher.

Copyright $\odot 2021$ Jing, Li, Li, Lei, Li, Yang, Zhang and Yang. This is an open-access article distributed under the terms of the Creative Commons Attribution License (CC $B Y)$. The use, distribution or reproduction in other forums is permitted, provided the original author(s) and the copyright owner(s) are credited and that the original publication in this journal is cited, in accordance with accepted academic practice. No use, distribution or reproduction is permitted which does not comply with these terms. 